\title{
IN BRINE
}

\section{Yang Pan, Chao $\mathrm{Wu}^{*}$ and Xin Huang}

School of Transportation Science and Engineering, Beihang University, 37 Xueyuan Road, Beijing 100191, China

*Corresponding author E-mail: wuchao@buaa.edu.cn

\section{ABSTRACT}

The corrosion of the concrete in the brine environment has been a challenging issue over years. $\mathrm{CaO}$-activated slag was reported to have an improved anti-corrosion property over the ordinary Portland cement, but its shrinkage cracking remained a problem. MgO-activated slag had lower shrinkage and greater potential of improved corrosion resistance. However, its long-term behavior in the brine environment was still unknown. This paper presents an experimental testing on the durability of the $\mathrm{MgO}$-activated slag paste when cured in the brine. Cube samples were prepared and cured in four single salt solutions and three mixed double-salt solutions. Each single salt solution contained one of the four chemicals of $\mathrm{NaCl}$, $\mathrm{Na}_{2} \mathrm{SO}_{4}, \mathrm{MgCl}_{2}, \mathrm{MgSO}_{4}$. The mixed double-salt solutions were " $\mathrm{NaCl}+\mathrm{Na}_{2} \mathrm{SO}_{4}$ ", "NaCl + $\mathrm{MgCl}_{2}$ ", " $\mathrm{Na}_{2} \mathrm{SO}_{4}+\mathrm{MgSO}_{4}$ ", with various molar ratios. The compressive strength of the $\mathrm{MgO}$-activated slag samples cured in the different solutions was tested at different ages up to 365 days. The experimental results indicated that the $\mathrm{MgO}$-activated slag could hardly sustain the strength after 150 days when cured in the brine solutions. It seemed that $\mathrm{SO}_{4}{ }^{2-}>\mathrm{Cl}^{-}$and $\mathrm{Mg}^{2+}>\mathrm{Na}^{+}$in terms of the corrosion damage to the $\mathrm{MgO}$-slag paste. As indicated by the 
X-ray diffraction (XRD) and the scanning electron microscopy (SEM) testing, the strength

degradation was mainly attributed to the consumption of the $\mathrm{CSH}$ in the acid solution (i.e.

$\mathrm{MgCl}_{2}$ or $\mathrm{MgSO}_{4}$ ), and the generation of the expansive $\mathrm{AFt}$ in the solutions of $\mathrm{SO}_{4}{ }^{2-}$ (i.e.

$\mathrm{Na}_{2} \mathrm{SO}_{4}$ or $\left.\mathrm{MgSO}_{4}\right)$. Finally, it was recommended that MgO-slag should not be used for the

construction of the concrete structures in the salt lake areas.

KEYWORDS: Concrete; Slag; Corrosion; Durability; Brine; Strength

\section{INTRODUCTION}

As the main construction material all over the world [1-3], concrete has been facing a challenging issue of corrosion especially when used in the offshore structures, or the structures built on saline rich soil. For example, many existing concrete piles in the salt lake area in the west of China $[4,5]$ were found severely corroded after just 5 years of service time [5-7]. For the offshore structures, the concrete corrosions were observed generally no later than 20 years [6-9]. The damages caused by the concrete corrosion have greatly impeded the local economy development of those areas, and thus the demand for the structural repair and the other anti-corrosion measures are increasing [10-13].

It has been well documented [14-19] that the concrete corrosion was mainly

40 attributed to the chemical degradation of the cementitious material in the brine environment.

41 Ions like $\mathrm{Na}^{+}, \mathrm{Mg}^{2+}, \mathrm{Cl}^{-}, \mathrm{SO}_{4}{ }^{2-}$, would react with the raw material or the hydration products of 42 the cement, leading to the strength loss of the concrete. It was reported that [14-20] the 43 ordinary Portland cement concrete (OPC) would be destroyed in 1 to 3 years in the salt lake 44 area [20]. This is because [21] $\mathrm{SO}_{4}{ }^{2-}$ would react with the calcium aluminate (CA) in the 
concrete, and generate considerable hydrated calcium aluminate sulfate (AFt). AFt is expansive and causes the cracking of the concrete, leading to the strength reduction $[7,22$, 23]. High strength concrete (HSC) or high performance concrete (HPC) is denser and more compact than $\mathrm{OPC}$, and thus could delay the penetration of $\mathrm{SO}_{4}{ }^{2-}$. However, these materials were still found corroded within 7 to 14 years [20].

In addition to the OPC concrete, there are also other types of concrete materials, including high alumina cement concrete (HAC), sulphoalumate cement concrete (SCC), magnesium oxychloride cement concrete (MOC) and polymer impregnated concrete (PIC). Unfortunately, they also suffer from the corrosion problems. For example, CAH (the hydrate of $\mathrm{HAC}$ or $\mathrm{SCC}$ ) would react with $\mathrm{SO}_{4}{ }^{2-}$ and generate $\mathrm{AFt}$, which would expand and cause cracking of the concrete $[24,25]$. The hydrate phase of the MOC was reported [26] unstable when cured in the natural brine environment [26]. PIC presented corrosion-resistance property when cured in the brine [27], but the cost of the PIC is too high to be used in large quantity in the engineering projects [28-30]. In order to prevent the corrosive ions attacking the concrete material, the structural elements were wrapped with anti-corrosion rolls in some projects in the salt lake area [31], but the corrosion still could not be effectively prevented, and the cost of rebuilding was expensive [31].

$\mathrm{CaO}$-activated slag exhibited desirable salt-corrosion resistance in comparison with the other existing cements, when cured in the brine of low concentration (i.e. $10 \mathrm{wt} . \% \mathrm{NaCl}$ solution for 180 days) [17, 32]. However, the engineering application of the CaO-activated slag was limited due to its significant shrinkage in air $[33,34]$. If the $\mathrm{CaO}$-activated slag was used for the construction of piles buried in the soil (where the holes of the soil are filled with 

the expansive AFt is still inevitable because the $\mathrm{SO}_{4}{ }^{2-}$ in the brine will react with $\mathrm{Ca}^{2+}$ and $\mathrm{Al}^{3+}$ in the $\mathrm{CaO}$-activated slag. Then the question is, if some other activation agent (without $\left.\mathrm{Ca}^{2+}\right)$ is used in the slag, will it present improved corrosion resistance in the brine? $\mathrm{MgO}$-activated slag (MgO-slag) was developed in the last decade, and it achieved a higher strength than the $\mathrm{CaO}$-slag as reported in [35-38]. Extensive microstructural investigations revealed that the main hydration products of the $\mathrm{MgO}$-slag were mainly calcium silicate hydrate $(\mathrm{CSH})$, hydrotalcite $(\mathrm{Ht}), \mathrm{Ca}(\mathrm{OH})_{2}(\mathrm{CH})$ and etc. Therefore, if the $\mathrm{MgO}$-slag is used as the cementitious material for the construction of the concrete piles buried in the saline soil containing $\mathrm{SO}_{4}{ }^{2-}$, the concrete damage by the expansive AFt might be alleviated as there is less $\mathrm{Ca}^{2+}$ in the MgO-slag. Surprisingly, there is still no long-term durability testing results of the $\mathrm{MgO}$-slag samples cured in the brine [35-37] in the literature. the MgO-slag paste when cured in the brine [35-38]. The effects of different ions in the brine on the strength degradation with time of the MgO-slag samples were investigated. The saturated solutions containing one of the four chemicals $\left(\mathrm{NaCl}, \mathrm{Na}_{2} \mathrm{SO}_{4}, \mathrm{MgCl}_{2}, \mathrm{MgSO}_{4}\right)$ were prepared, and the $\mathrm{MgO}$-slag samples were immerged and cured in each solution for up to 1 year. The strength of the $\mathrm{MgO}$-slag samples at different age was tested to analyze the trend of the strength degradation. The mixed saturated solution of " $\mathrm{NaCl}+\mathrm{Na}_{2} \mathrm{SO}_{4}$ ", $\mathrm{NaCl}+$ $\mathrm{MgCl}_{2}$ " and " $\mathrm{Na}_{2} \mathrm{SO}_{4}+\mathrm{MgSO}_{4}$ " were also prepared with various ion molar ratios (e.g.

$\left.87 \mathrm{Cl}^{-} / \mathrm{SO}_{4}{ }^{2-}, " \mathrm{Na}^{+} / \mathrm{Mg}^{2+»}\right)$, to study the concentration effects of the different ions on the strength development of the MgO-slag. For comparison purpose, OPC samples were also prepared in 
the same brine solutions and the strength at different ages was also tested. Finally, the chemical composition and the microstructure of the cured products were analyzed using the X-ray diffraction (XRD) and the scanning electron microscopy (SEM) respectively. The underlying micro mechanism of the long-term strength development of the $\mathrm{MgO}$-slag cured in brine was discussed and reported.

\section{MATERIALS AND EXPERIMENTAL PROGRAM}

\subsection{Materials}

In this paper, MgO-slag was prepared with a mixture of two components, the slag and the

$\mathrm{MgO}$ powder. The slag was provided by the Beijing Shougang Co. Ltd with a specific surface area of $400 \mathrm{~m}^{2} / \mathrm{kg}$. The detailed chemical compositions of the slag and the $\mathrm{MgO}$ powder are shown in Table 1 and Table 2, respectively. The slag was also tested using XRD and the pattern is shown in Fig. 1(a). The $\mathrm{MgO}$ powder was an industrial material with a tested activity of $40 \%$ according to the chemistry and technology of magnesia [39]. The $\mathrm{MgO}$ powder was grinded and sieved to the size under $150 \mu \mathrm{m}$ in diameter. The XRD pattern of the $\mathrm{MgO}$ powder is shown in Fig. 1(b). In order to compare with the MgO-slag, the reference cement was also prepared which is normally the main composition of OPC. The reference cement was provided by the China United Cement Co. Ltd. The chemical composition of the reference cement is listed in Table 3, and its mineral composition is presented in Table 4. solutions, single salt solution and mixed double-salt solution. Four single salt solutions were prepared, with each containing one of the four chemicals $\mathrm{NaCl}, \mathrm{Na}_{2} \mathrm{SO}_{4}, \mathrm{MgCl}_{2}$ and $\mathrm{MgSO}_{4}$. 
111 The single salt solutions were prepared by mixing $\mathrm{NaCl}, \mathrm{Na}_{2} \mathrm{SO}_{4}, \mathrm{MgCl}_{2} \cdot 6 \mathrm{H}_{2} \mathrm{O}$,

$112 \mathrm{MgSO}_{4} \cdot 7 \mathrm{H}_{2} \mathrm{O}$ with the tap water at $25{ }^{\circ} \mathrm{C}$ according to [40]. The chemicals were supplied by

113 the Beijing Sinopharm Chemical Co. Ltd. Three types of mixed double-salt solutions were

114 prepared. Each solution was a mixture of two chemicals with the tap water, e.g. " $\mathrm{NaCl}+$

$115 \mathrm{Na}_{2} \mathrm{SO}_{4}$ ", "NaCl$+\mathrm{MgCl}_{2}$ ", " $\mathrm{Na}_{2} \mathrm{SO}_{4}+\mathrm{MgSO}_{4}$ ". For each mixed double-salt solution, the

116 molar ratio of the two chemicals was varied. For example, $\mathrm{NaCl} / \mathrm{Na}_{2} \mathrm{SO}_{4}$ ratio was selected as

$1170.5,2,4$ and 6. And the ratios of the two solutions of $\mathrm{NaCl} / \mathrm{MgCl}_{2}$ and $\mathrm{Na}_{2} \mathrm{SO}_{4} / \mathrm{MgSO}_{4}$

118 changed as 2,6 and 9. The purpose of changing the molar ratio was to study the effects of the

119 concentration variation of the chemicals on the mechanical degradation of the samples. In

120 addition, different molar ratios represent the concentration change of different ions in the

121 natural environments in China. For example, the concentration variation of $\mathrm{Na}^{+}, \mathrm{Mg}^{2+}, \mathrm{Cl}^{-}$

122 and $\mathrm{SO}_{4}{ }^{2-}$ ions in Ge'ermu City in China was reported in [5]. Even in the same city, the

123 concentration of the same ion could vary to a much extent. As reported in [5], the mass

124 content of $\mathrm{Na}^{+}$in the brine could range from $0.09 \%$ to $9.47 \%$. Therefore, the selected molar

125 ratios of the mixed salt solutions could well cover the variation of the ions in the natural

126 environment. When preparing the brine solutions, the tap water was added to the chemical

127 powders very slowly, and at the same time carefully stirred with a glass bar. The solutions

128 were ready for use when a little chemical residue was left at the bottom of the container at

$12925^{\circ} \mathrm{C}$. All the containers were sealed during the curing process of the MgO-slag and the

130 reference cement samples. 
133 Table 1 The chemical composition of the slag (wt.\%)

\begin{tabular}{|c|c|c|c|c|c|c|c|c|c|c|}
\hline $\mathrm{CaO}$ & $\mathrm{SiO}_{2}$ & $\mathrm{Al}_{2} \mathrm{O}_{3}$ & $\mathrm{Fe}_{2} \mathrm{O}_{3}$ & $\mathrm{MgO}$ & $\mathrm{Na}_{2} \mathrm{O}$ & $\mathrm{K}_{2} \mathrm{O}$ & $\mathrm{SO}_{3}$ & $\mathrm{MnO}$ & $\mathrm{P}_{2} \mathrm{O}_{5}$ & $\mathrm{Cl}$ \\
\hline 44.06 & 28.72 & 15.13 & 0.83 & 5.34 & 0.2 & 0.47 & 3.81 & 0.23 & 0.08 & 0.06 \\
\hline
\end{tabular}

134 Table 2 The chemical composition of the $\mathrm{MgO}$ powder (wt.\%)

\begin{tabular}{|l|l|l|l|l|l|}
\hline $\mathrm{MgO}$ & $\mathrm{CaO}$ & $\mathrm{SiO}_{2}$ & $\mathrm{Al}_{2} \mathrm{O}_{3}$ & $\mathrm{Fe}_{2} \mathrm{O}_{3}$ & others \\
\hline 81.36 & 2.11 & 2.72 & 0.20 & 0.33 & 13.28 \\
\hline
\end{tabular}

135 Table 3 The chemical composition of the reference cement (wt.\%)

\begin{tabular}{|c|c|c|c|c|c|c|c|c|c|c|}
\hline Composition & $\mathrm{SiO}_{2}$ & $\mathrm{Al}_{2} \mathrm{O}_{3}$ & $\mathrm{Fe}_{2} \mathrm{O}_{3}$ & $\mathrm{CaO}$ & $\mathrm{MgO}$ & $\mathrm{SO}_{3}$ & $\mathrm{Na}_{2} \mathrm{Oeq}$ & $\mathrm{f}-\mathrm{CaO}$ & Loss & $\mathrm{Cl}^{-}$ \\
\hline Content & 20.760 & 4.580 & 3.270 & 62.130 & 3.130 & 2.800 & 0.057 & 0.760 & 1.860 & 0.013 \\
\hline
\end{tabular}

136 Table 4 The mineral composition of the reference cement (wt.\%)

\begin{tabular}{|c|c|c|c|c|c|}
\hline Composition & $\mathrm{C}_{3} \mathrm{~S}$ & $\mathrm{C}_{2} \mathrm{~S}$ & $\mathrm{C}_{3} \mathrm{~A}$ & $\mathrm{C}_{4} \mathrm{AF}$ & total \\
\hline Content & 56.62 & 19.58 & 6.36 & 10.49 & 93.05 \\
\hline
\end{tabular}
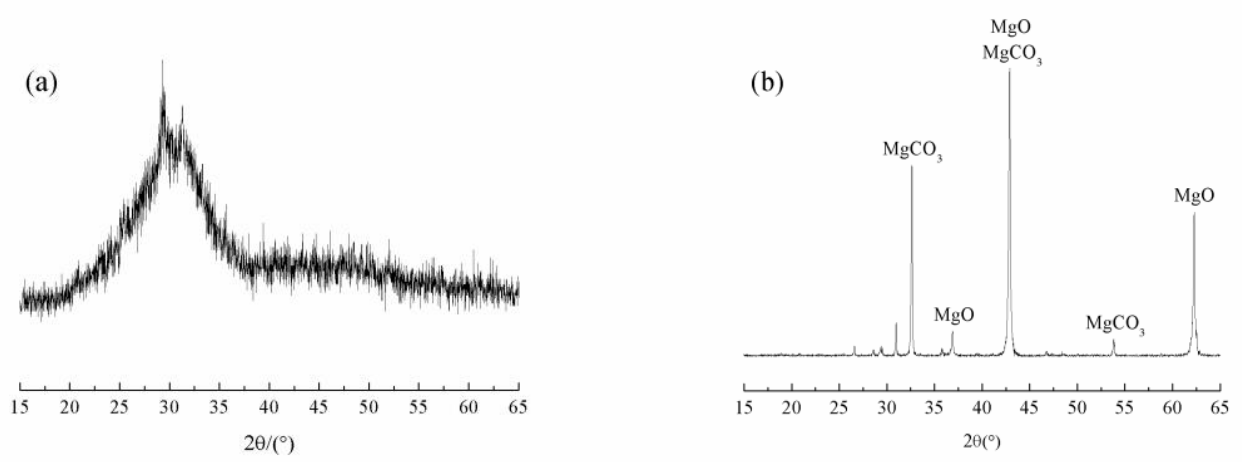

137

138

Fig. 1. XRD patterns of (a) the slag; and (b) the $\mathrm{MgO}$ powder

139

\subsection{Sample preparation}

141 Cube samples of the MgO-slag and the reference cement were prepared with a dimension of

$14220 \times 20 \times 20 \mathrm{~mm}^{3}$. The mix proportion of the MgO-slag was MgO/slag/tap water=1:9:3

143 (weight ratio), while one part of the reference cement was mixed with 0.24 (weight ratio) part

144 of the tap water to prepare the cube samples. The mix proportions of the MgO-slag and the

145 reference cement were selected to achieve the reasonable strength. During the preparation

146 process, the fresh pastes of the two materials were poured into a steel mold with a dimension 
147 of $20 \times 20 \times 20 \mathrm{~mm}^{3}$. Then the mold was covered using a plastic wrap, and placed in the lab

148 at an average temperature of about $17{ }^{\circ} \mathrm{C}$. The samples of the reference cement were

149 demolded after 1 day, and the MgO-slag samples were demolded after 7 days, when both

150 materials achieved adequate strength for demolding.

151 After demolding, the samples were immerged and cured in the single salt solutions

152 and the mixed double-salt solutions (as mentioned in Section 2.1) until the specified age. The

153 samples were also immerged and cured in the tap water for the comparison purpose. In each

154 curing tank, the volume ratio between the samples and the liquid solution were 1:5. The

155 curing temperature of all samples was about $17{ }^{\circ} \mathrm{C}$. The samples were all immerged in the

156 brine solutions in order to simulate the pile applications, in which the materials were buried

157 underground and immerged in the brine solutions. Since all the samples were immerged and

158 cured in the solutions, the curing humidity was $100 \%$. The demolding time may affect the

159 initial strength of the $\mathrm{MgO}$-slag and the reference cement. However, if the strength at

160 different age was normalized by the initial strength to evaluate the trend of the strength

161 development, the demolding time would have little effect and the strength development in the

162 brine solutions may be mainly attributed to the chemical attack. More details will be

163 discussed in Section 3.

$165 \quad 2.3$ Experimental testing

166 (1) Compressive testing

167 Compression tests were conducted on the samples at the age of 3 days, 7 days, 28 days, 60

168 days, 90 days, 150 days, 210 days and 365 days. The universal testing machine from Beijing 
169 Gongju Factory was used with a loading capacity of $100 \mathrm{kN}$. The loading rate was $1 \mathrm{~mm} / \mathrm{min}$.

170 At least three samples of the same curing condition were tested for repeating purpose, and the

171 average compressive strength and the corresponding coefficient of variation (COV) were

172 recorded. The dimension of the samples and the procedure of the compressive tests were also

173 adopted by the other researchers [41-43].

(2) X-ray diffraction (XRD) testing

176 XRD testing was used to analyze the chemical change of the samples. Firstly, the cube

177 samples were dried in an oven at $60{ }^{\circ} \mathrm{C}$ until the weight of the samples did not change. Then a

178 little piece was collected from the center of each cube sample. Then the piece was grinded

179 into powder and sieved to the size under $75 \mu \mathrm{m}$ in diameter. Then this powder was analyzed

180 using XRD machine from PANalytical Empyrean of model P3. The testing parameters were

181 set at $40 \mathrm{kV}, 40 \mathrm{~mA}, \mathrm{Cu} / \mathrm{K} \alpha$. The powder was scanned at an angle (20) ranging between 15

182 degrees and 65 degrees, at a scanning speed of 0.2 s/step, with a resolution of 0.026

183 degree/step.

184

\section{5 (3) Scanning electron microscope (SEM) analysis}

186 The microstructure of the dried samples was also analyzed using SEM. The cube samples

187 were dried in an oven at $60{ }^{\circ} \mathrm{C}$ until the weight of the samples did not change. The SEM

188 instrument was from JEOL Inc., and the model was JSM-7500F. The amplification factor was 300 times. 


\section{EXPERIMENTAL RESULTS AND DISCUSSIONS}

3.1 Strength development of the MgO-slag and the reference cement paste in the single

193

194

195

196

197

198

\section{salt solutions}

The strength development curves of the MgO-slag and the reference cement paste, which were cured in the different single salt solutions, are plotted in Fig. 2(a) and Fig. 2(b), respectively. This work focused on the strength development trend of the MgO-slag and the reference cement paste when cured in various brine solutions, so the initial strength was of less importance when evaluating the strength development trend. Therefore, the "strength ratio (\%)" was used as the vertical axis in Fig. 2. The "strength ratio (\%)" means, for each curve, the strength at different ages $(7,28,60,150,210,365$ days) was normalized by the strength at 7 days. The absolute compressive strength of the MgO-slag samples cured in the tap water, the saturated solutions of $\mathrm{NaCl}, \mathrm{Na}_{2} \mathrm{SO}_{4}, \mathrm{MgCl}_{2}, \mathrm{MgSO}_{4}$ at the age of 7 days were 4.8 $\mathrm{MPa}, 9.1 \mathrm{MPa}, 14.4 \mathrm{MPa}, 3.6 \mathrm{MPa}, 9.6 \mathrm{MPa}$, and the strength of the reference cement at the age of 3 days were $53.2 \mathrm{MPa}, 46.6 \mathrm{MPa}, 60.1 \mathrm{MPa}, 38.9 \mathrm{MPa}, 56.3 \mathrm{MPa}$. The comparison on the absolute strength values in various single solutions will be discussed in the next section. It should be noted that, the age in this paper refers to the absolute time that the samples were immerged in the brine solutions, excluding the demolding time (e.g. 1 day for the reference cement paste and 7 days for the MgO-slag paste). The curves of the MgO-slag paste in Fig. 2(a) were plotted using solid symbols, while the curves of the reference cement paste in Fig. 2(b) were presented with hollow symbols.

It can be seen in Fig. 2(a) that, when cured in the tap water, the strength of the MgO-slag continuously increased up to 365 days (almost $400 \%$ increase comparing to the 
213 strength at 7 days). On the other hand, when cured in the single salt solutions, the strength 214 development was different between the $\mathrm{Na}^{+}$rich solutions (e.g. $\mathrm{NaCl}$ or $\mathrm{Na}_{2} \mathrm{SO}_{4}$ ) and the $215 \mathrm{Mg}^{2+}$ rich solutions $\left(\mathrm{MgCl}_{2}\right.$ or $\left.\mathrm{MgSO}_{4}\right)$. For $\mathrm{Na}^{+}$rich solutions, a two-stage strength 216 development was observed for the MgO-slag samples. The strength firstly increased upto 150 217 days, after which the strength drop dramatically. For example, the strength in the $\mathrm{Na}_{2} \mathrm{SO}_{4}$ solution increased by $150 \%$ at 150 days while drop to zero after 210 days, comparing to the 219 strength at 7 days. On the other hand, when cured in the $\mathrm{Mg}^{2+}$ rich solutions, the $\mathrm{MgO}-\mathrm{slag}$ 220 paste totally lost strength after only 28 days. It should be noted in Fig. 2 that, the strength 221 dropped to zero means that the samples were totally damaged (see Fig. 3) after the curing in the corresponding single salt solution, making it impossible to do the compressive testing. There are two interesting observations in Fig. 2(a). For the first observation, in the $\mathrm{Na}^{+}$rich solutions, $\mathrm{MgO}$-slag paste's strength increased in the first stage, but at a lower speed comparing to the samples cured in the tap water. In the second stage, the strength dropped to almost zero. It seems that there are two competing mechanisms which contribute to the two-stage strength development. The first mechanism is the strength build-up mechanism which is the same as the curing process in the tap water. The second mechanism is the corrosion damage due to the salt solution. In the first stage, the curing mechanism was

230 dominant so that the strength kept increasing, though the speed was lowered by the corrosion 231 mechanism. In the second stage after 150 days, the corrosion mechanism overtook the curing 232 mechanism and the strength dramatically dropped. The second interesting observation is that the MgO-slag paste could not develop any strength in the $\mathrm{Mg}^{2+}$ rich solutions. It indicates that 234 the corrosion damage in the $\mathrm{Mg}^{2+}$ rich solutions may be much more severe than that in the 
$\mathrm{Na}^{+}$rich solutions.

The strength development curves of the reference cement paste in various single salt

237 solutions are shown in Fig. 2(b). It is obvious that the reference cement paste could hardly

238 sustain its strength when cured in any single salt solution, though the strength in the tap water

239 increased linearly up to 365 days. Comparing to the curves in Fig. 2(a), it is clear that the

240 reference cement paste is more sensitive to the corrosion damage than the MgO-slag paste

241 when cured in the single salt solutions.
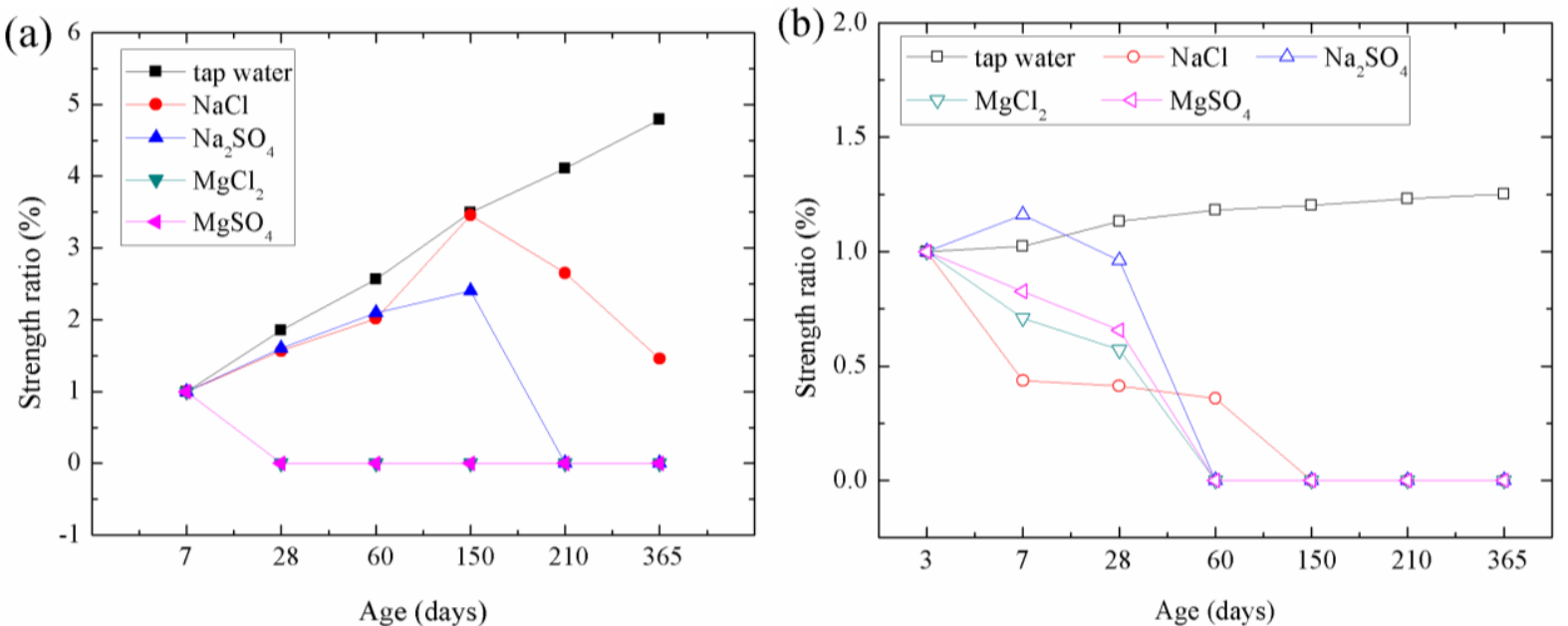

Fig. 2. The strength development curves of (a) the MgO-slag paste and (b) the reference cement paste in different single salt solutions
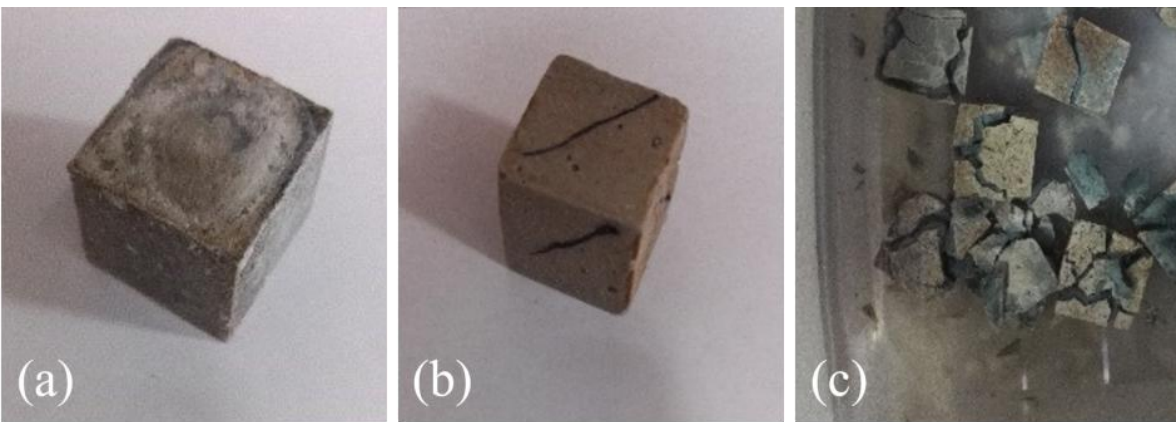

Fig. 3. The appearance of the MgO-slag paste after 365 days curing in the (a) tap water; (b) single $\mathrm{NaCl}$ solution and (c) single $\mathrm{Na}_{2} \mathrm{SO}_{4}$ solution 


\subsection{Strength development of the MgO-slag in the mixed double-salt solutions}

250 To further investigate the strength development of the MgO-slag paste, the samples were also cured in three mixed double-salt solutions. They were " $\mathrm{NaCl}+\mathrm{Na}_{2} \mathrm{SO}_{4}$ ", "NaCl$+\mathrm{MgCl}_{2} "$ and " $\mathrm{Na}_{2} \mathrm{SO}_{4}+\mathrm{MgSO}_{4}$ " solutions. The reference cement samples were not tested as they could not sustain the strength in any single salt solution. The strength development curves of the MgO-slag paste in the three mixed double-salt solutions are presented in Figs. 4(a) to (c) respectively. Different from Fig. 2, the absolute strength values were used in Fig. 4 in order to identify which ions play a more important role in the corrosion damage mechanism to the MgO-slag paste.

In Fig. 4(a), the two-stage strength development pattern was observed again for the

MgO-slag paste cured in the mixed " $\mathrm{NaCl}+\mathrm{Na}_{2} \mathrm{SO}_{4}$ " solution. The turning point was still at the age of 150 days. It is interesting that the strength in the single $\mathrm{NaCl}$ solution was always lower than that in the single $\mathrm{Na}_{2} \mathrm{SO}_{4}$ solution at any age within 150 days. With the increase of the molar ratio of $\mathrm{NaCl} / \mathrm{Na}_{2} \mathrm{SO}_{4}$, the strength curve gradually shifted from $\mathrm{Na}_{2} \mathrm{SO}_{4}$ curve to the $\mathrm{NaCl}$ curve. However, when the age exceeded 150 days, the MgO-slag samples could not sustain any compressive load in the existence of $\mathrm{SO}_{4}{ }^{2-}$. This indicates that the corrosion damage due to $\mathrm{SO}_{4}{ }^{2-}$ was more severe than that caused by $\mathrm{Cl}^{-}$.

In Fig. 4(b), the strength curves of the MgO-slag paste cured in the mixed solution of $\mathrm{NaCl} / \mathrm{MgCl}_{2}$ with various molar ratios were compared. It seems that, the $\mathrm{Mg}^{2+}$ plays a more dominant role than $\mathrm{Na}^{+}$in terms of introducing the corrosion damage to the $\mathrm{MgO}$-slag paste. With the increase of the molar ratio of $\mathrm{NaCl} / \mathrm{MgCl}_{2}$ from 2 to 9 , the strength curve shifted from the curve of the single $\mathrm{NaCl}$ solution to that of the single $\mathrm{MgCl}_{2}$ solution. This 
271 argument is further supported by the observation in Fig. 4(c). In other words, when the

$272 \mathrm{MgO}$-slag paste was cured in the mixed " $\mathrm{Na}_{2} \mathrm{SO}_{4}+\mathrm{MgSO}_{4}$ " solution, the strength would

273 decrease with the increase of the $\mathrm{Mg}^{2+}$ concentration. It is obvious in Fig. 4(c) that, the

274 strength curve gradually dropped from the curve of the single $\mathrm{Na}_{2} \mathrm{SO}_{4}$ solution to that of the

275 single $\mathrm{MgSO}_{4}$ solution with the decrease of their molar ratio.

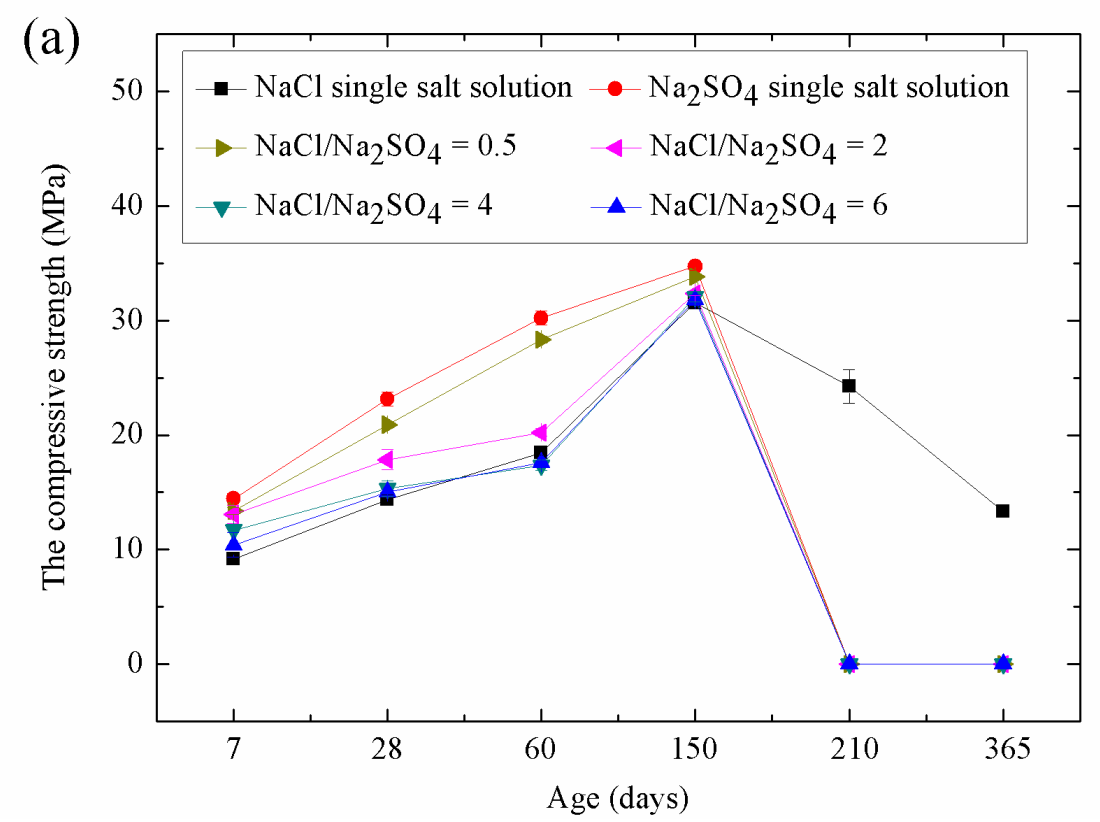

276

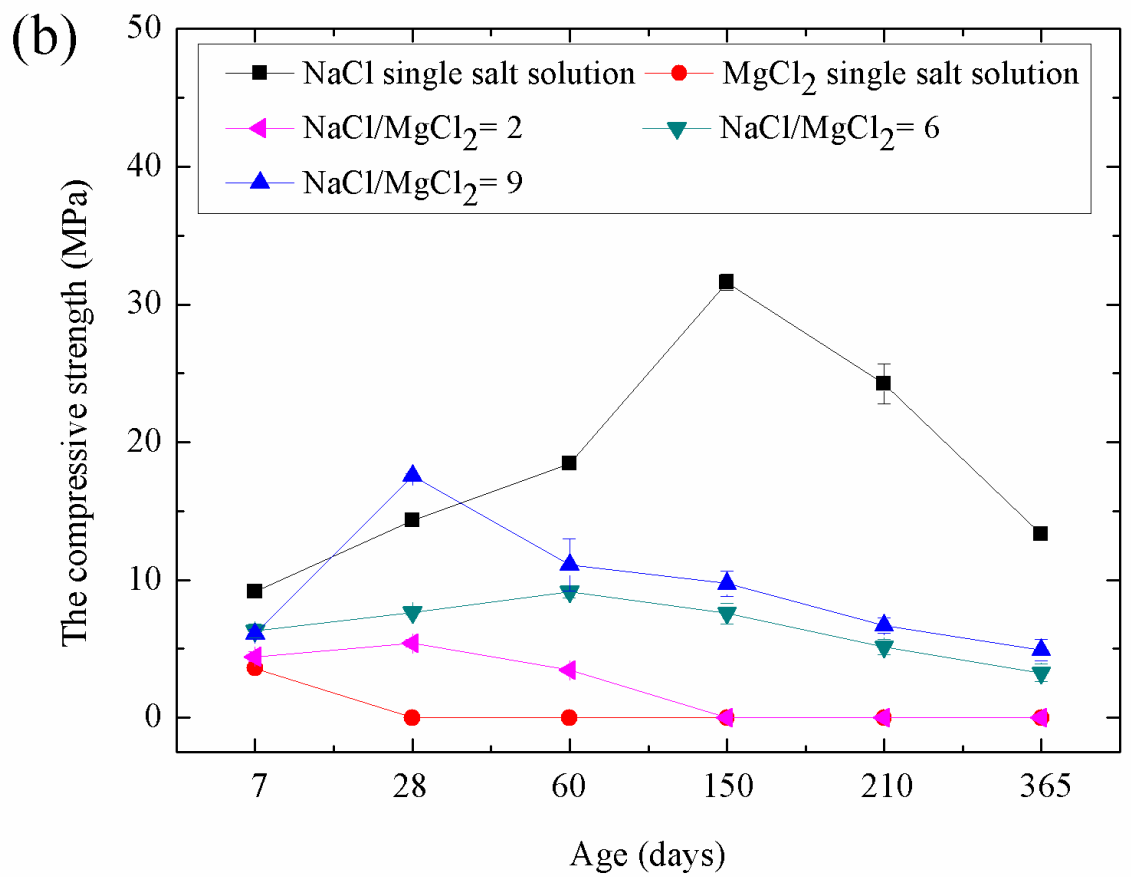




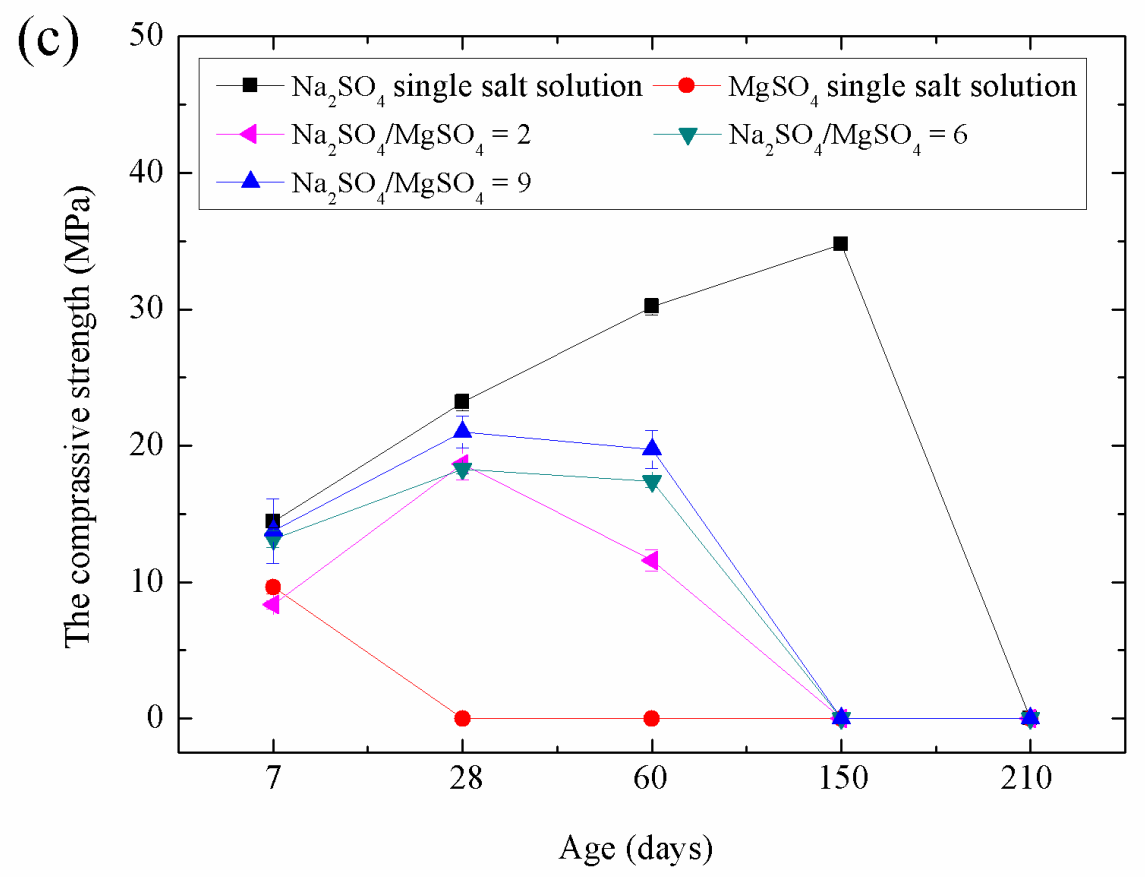

Fig. 4. The strength development curves of the MgO-slag paste in the mixed double-salt solutions of the (a) $\mathrm{NaCl}+\mathrm{Na}_{2} \mathrm{SO}_{4}$; (b) $\mathrm{NaCl}+\mathrm{MgCl}_{2}$ and (c) $\mathrm{Na}_{2} \mathrm{SO}_{4}+\mathrm{MgSO}_{4}$ Considering the results in Fig. 4, it can be concluded that $\mathrm{SO}_{4}{ }^{2-}>\mathrm{Cl}^{-}$, and $\mathrm{Mg}^{2+}>$

$283 \mathrm{Na}^{+}$in terms of the corrosion damage to the $\mathrm{MgO}$-slag paste. $\mathrm{For}^{\mathrm{SO}_{4}}{ }^{2-}>\mathrm{Cl}^{-}$, this may be 284 because the expansive AFt is more likely to be generated when more $\mathrm{SO}_{4}{ }^{2-}$ exists, causing cracking of the MgO-slag paste. This argument is evidenced by the appearance of the $286 \mathrm{MgO}$-slag paste cured in the mixed " $\mathrm{NaCl}+\mathrm{Na}_{2} \mathrm{SO}_{4}$ " solution in Fig. 5. It can be seen in Fig. 2875 that, the $\mathrm{MgO}$-slag paste were damaged more severely with the increase of the $\mathrm{SO}_{4}{ }^{2-}$ 288 concentration in the mixed solution. For $\mathrm{Mg}^{2+}>\mathrm{Na}^{+}$, this is because the $\mathrm{pH}$ of the $\mathrm{MgCl}_{2}$ or 289 the $\mathrm{MgSO}_{4}$ solution is lower than 7 (acid). However, the hydrate of the MgO-slag paste is 290 alkaline. Therefore, the $\mathrm{MgO}$-slag paste could not be stable in the solution of $\mathrm{MgCl}_{2}$ or $291 \mathrm{MgSO}_{4}$. 
293
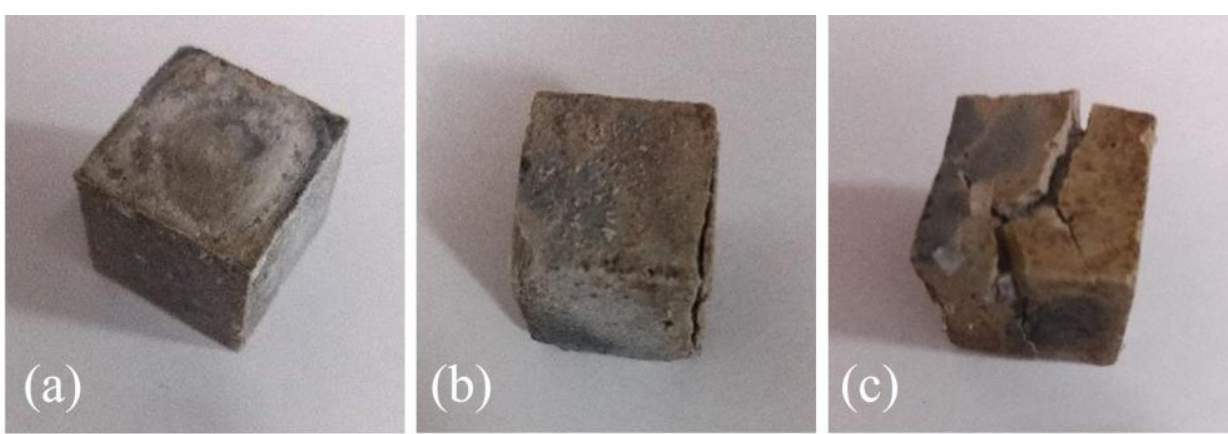

Fig. 5. The appearance of the MgO-slag samples after 365 days curing in the (a) tap water; (b)

$$
\mathrm{NaCl} / \mathrm{Na}_{2} \mathrm{SO}_{4}=6 \text { and (c) } \mathrm{NaCl} / \mathrm{Na}_{2} \mathrm{SO}_{4}=4
$$

\section{CHEMICAL AND MICROSTRUCTURAL CHARACTERIZATION OF THE}

\section{MGO-SLAG HYDRATE}

\subsection{XRD testing results}

The XRD patterns of the MgO-slag paste after 356 days curing in the single $\mathrm{NaCl}$ solution, mixed " $\mathrm{NaCl}+\mathrm{Na}_{2} \mathrm{SO}_{4}$ " solution with a molar ratio of 4 and the single $\mathrm{Na}_{2} \mathrm{SO}_{4}$, are presented in Figs. 6(b) to (d), respectively. The XRD pattern of the MgO-slag paste cured in the tap water [36] was also presented in Fig. 6(a) for comparison purpose. This is to study the chemical change in the MgO-slag hydrate due to the variation of the $\mathrm{Cl}^{-}$and $\mathrm{SO}_{4}{ }^{2-}$ concentrations. For the $\mathrm{NaCl} / \mathrm{Na}_{2} \mathrm{SO}_{4}$ mixed solution, the molar ratio of 4 was selected, because the samples cured in the $\mathrm{NaCl} / \mathrm{Na}_{2} \mathrm{SO}_{4}$ solution with other molar ratios showed the same trend of the mechanical degradation (see Fig. 4a).

It can be seen in Fig. 6(b), when cured in the single $\mathrm{NaCl}$ solution, the hydration products of $\mathrm{CSH}, \mathrm{CH}, \mathrm{Ht}$ and $\mathrm{MgCO}_{3}$ were observed. $\mathrm{CSH}, \mathrm{CH}$ and $\mathrm{Ht}$ are the typical hydration products of the $\mathrm{MgO}$-slag when cured in the tap water (Fig. 6a [37]). $\mathrm{MgCO}_{3}$ 
311 should come from the industrial raw material of the $\mathrm{MgO}$ powder. The hydration products of 312 the $\mathrm{MgO}$-slag when cured in the mixed " $\mathrm{NaCl}+\mathrm{Na}_{2} \mathrm{SO}_{4}$ " solution (see Fig. 6c) were almost

313 the same as those in the single $\mathrm{NaCl}$ solution (see Fig. 6b). However, when cured in the 314 single $\mathrm{Na}_{2} \mathrm{SO}_{4}$ solution, one more hydration product was observed in Fig. 6(d), which was 315 AFt. AFt contained five chemical elements ( $\mathrm{Ca}, \mathrm{S}, \mathrm{Al}, \mathrm{O}$ and $\mathrm{H})$, with $\mathrm{S}$ from the solution of $316 \mathrm{Na}_{2} \mathrm{SO}_{4}$, and $\mathrm{Ca}, \mathrm{Al}$ from the slag. It is known that the strength of the MgO-slag paste is mainly contributed by the $\mathrm{CSH}$, while the $\mathrm{CH}, \mathrm{Ht}, \mathrm{AFt}$ and $\mathrm{MgCO}_{3}$ are dispersive particles. As indicated by the XRD patterns in Fig. 6, the intensity of the CSH peaks is very low [36] in the brine solutions, which was the main reason why the $\mathrm{MgO}$-slag dramatically lost strength after 365 days in the single and mixed solutions. Another reason of the strength loss was due to the generation of the expansive AFt with the existence of $\mathrm{SO}_{4}{ }^{2-}$ (see Fig. 6d). These XRD results support the arguments on the strength degradation mechanisms in Section 3.2. in Fig. 6. XRD patterns were analyzed using the most updated database in the software of Jade 6.5 with a PDF card of 2004. It seems that X could only be generated with the existence of $\mathrm{Cl}^{-}$because it disappeared in Fig. 6(d) when there was no $\mathrm{Cl}^{-}$. Although the chemical composition and its microstructure are unknown, the sharp peak of $X$ suggests that it would be a crystal rather than an amorphous material [44]. Therefore, its existence would not violate the above arguments on the strength degradation mechanism due to the decreasing of $\mathrm{CSH}$ and the generation of the expansive AFt. 
(a)

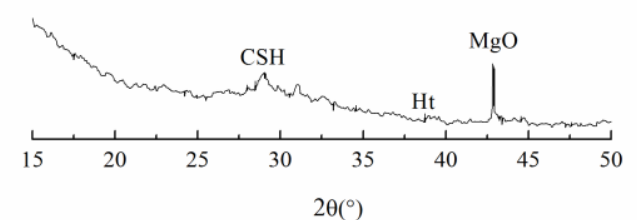

(c)

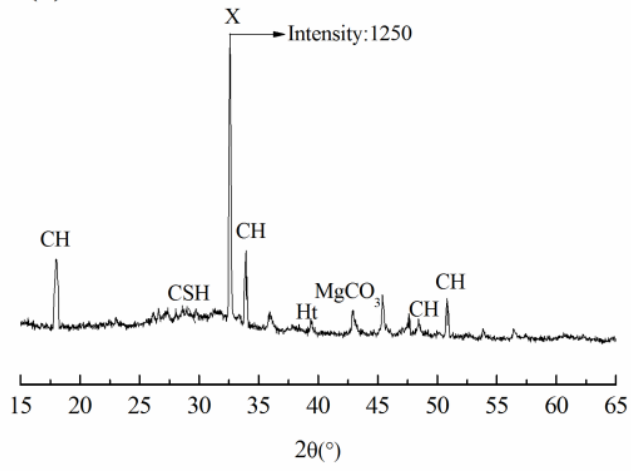

(b)

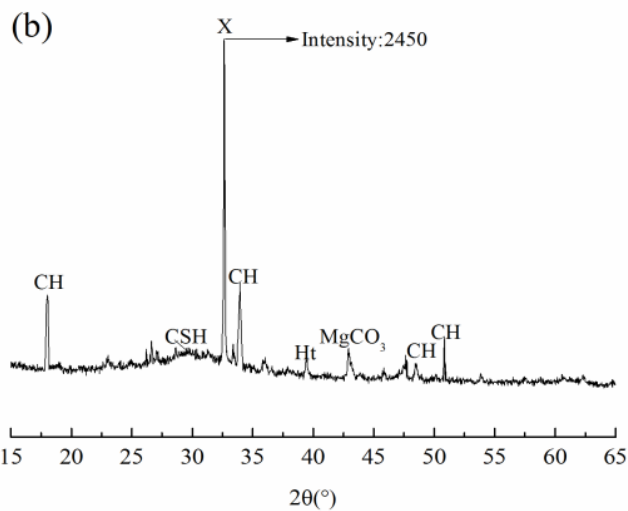

(d)

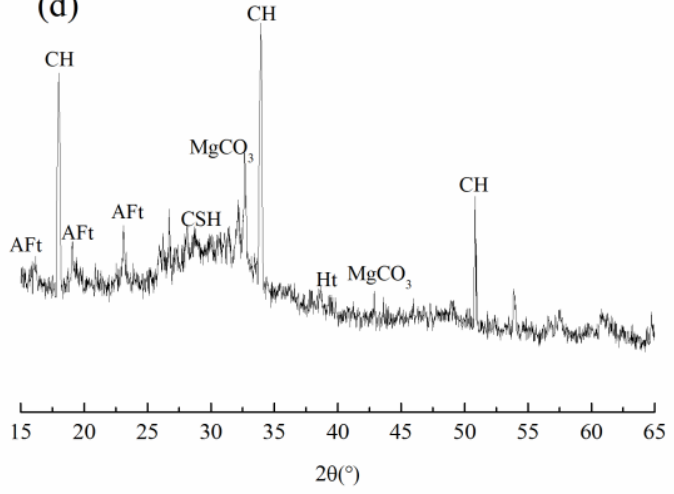

Fig. 6. XRD patterns of the MgO-slag samples after 365 days curing in the (a) tap water [36];

(b) single $\mathrm{NaCl}$ solution; (c) mixed $\mathrm{NaCl} / \mathrm{Na}_{2} \mathrm{SO}_{4}=4$ and (d) single $\mathrm{Na}_{2} \mathrm{SO}_{4}$ solution

\subsection{SEM results}

338 The microstructure of the MgO-slag paste was analyzed using the SEM after 365 days curing

339 in the three solutions: the single $\mathrm{NaCl}$ solution, mixed " $\mathrm{NaCl}+\mathrm{Na}_{2} \mathrm{SO}_{4}$ " solution with a

340 molar ratio of 4 , and the single $\mathrm{Na}_{2} \mathrm{SO}_{4}$ solution. The SEM images (with a magnification of

341300 times) of the MgO-slag samples in the three solutions are shown in Figs. 7(b) to (d),

342 respectively. The SEM image of the MgO-slag paste cured in the tap water [36] was also

343 presented in Fig. 7(a) for comparison purpose. 
347 the tap water, whereas the $\mathrm{CSH}$ disappeared when the MgO-slag paste was cured in the

348 solutions with $\mathrm{NaCl}$ or $\mathrm{Na}_{2} \mathrm{SO}_{4}$ (Figs. $7 \mathrm{~b}$ to d). In addition, extensive acicular crystals of the

349 AFt could be observed in Fig. 7(d) with the increase of $\mathrm{SO}_{4}{ }^{2-}$ in the solution. These SEM

350 observations again provided further microstructural evidences, supporting the XRD

351 arguments that, the damages to the MgO-slag paste were due to the decreasing of the CSH

352 and the generation of the expansive AFt.

353
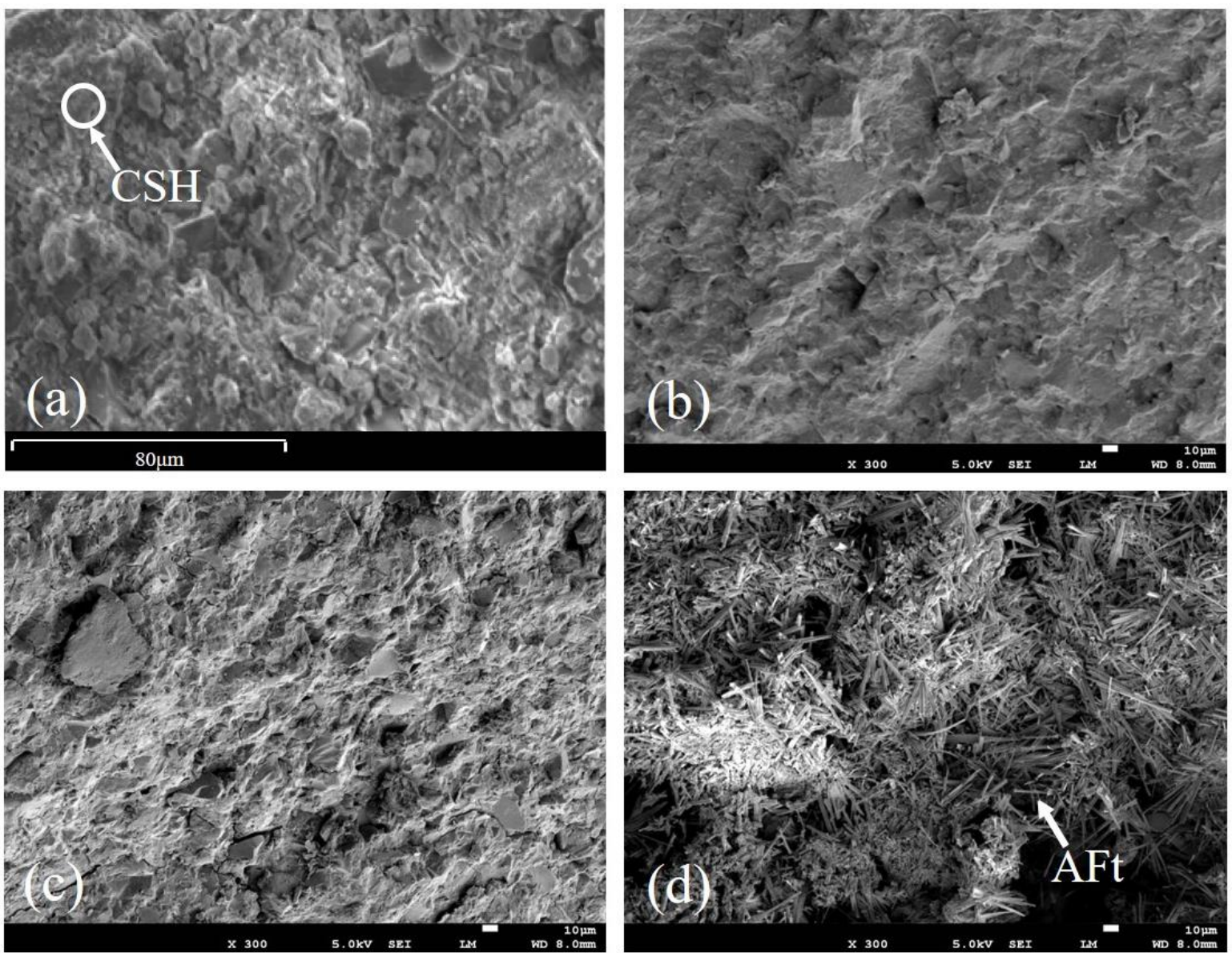

354

Fig. 7. Representative SEM images of the MgO-slag paste after 365 days curing in the

solution of the (a) tap water [36]; (b) single $\mathrm{NaCl}$ solution; (c) mixed $\mathrm{NaCl} / \mathrm{Na}_{2} \mathrm{SO}_{4}=4$ and (d) 


\section{CONCLUSIONS}

359 This paper investigated the long-term behavior of the MgO-slag paste when cured in the

360 single salt solutions and the mixed double-salt solutions. Four single salt solutions were

361 selected including $\mathrm{NaCl}, \mathrm{Na}_{2} \mathrm{SO}_{4}, \mathrm{MgCl}_{2}$, and $\mathrm{MgSO}_{4}$. Three mixed double-salt solutions were " $\mathrm{NaCl}+\mathrm{Na}_{2} \mathrm{SO}_{4}$ ", " $\mathrm{NaCl}+\mathrm{MgCl}_{2}$ ", and " $\mathrm{Na}_{2} \mathrm{SO}_{4}+\mathrm{MgSO}_{4}$ " with various molar ratios.

The strength development curves of the MgO-slag paste up to 365 days were developed when cured in these different solutions. The mechanisms of the strength degradation were revealed by using the chemical analysis with XRD and the microstructural investigation with SEM.

Based on the findings in this study, the following conclusions can be drawn:

(1) When cured in the $\mathrm{Na}^{+}$rich single salt solution (i.e. $\mathrm{NaCl}$ or $\mathrm{Na} 2 \mathrm{SO} 4$ ), the $\mathrm{MgO}$-slag paste could develop strength upto 150 days, after which the strength decreased gradually and dropped to zero after 1 year. When cured in the $\mathrm{Mg}^{2+}$ rich solutions (i.e. $\mathrm{MgCl}_{2}$ or $\mathrm{MgSO}_{4}$ ), the $\mathrm{MgO}$-slag paste could not develop any strength after 7 days.

(2) The results of the single salt solution and the mixed double-salt solution indicated that, $\mathrm{SO}_{4}{ }^{2-}>\mathrm{Cl}^{-}$and $\mathrm{Mg}^{2+}>\mathrm{Na}^{+}$in terms of the corrosion damage to the $\mathrm{MgO}$-slag paste.

(3) The corrosion damage to the MgO-slag could be caused by two reasons. One was the consumption of the $\mathrm{CSH}$ in the acid solution (i.e. $\mathrm{MgCl}_{2}$ or $\mathrm{MgSO}_{4}$ ), and the other was the generation of the expansive AFt in the solutions of $\mathrm{SO}_{4}{ }^{2-}$ (i.e. $\mathrm{Na}_{2} \mathrm{SO}_{4}$ or $\mathrm{MgSO}_{4}$ ).

(4) The underlying strength degradation mechanisms of the MgO-slag paste were supported by the chemical analysis using XRD and the microstructural investigation using SEM. It was observed that, with the increase of $\mathrm{SO}_{4}{ }^{2-}$, the $\mathrm{CSH}$ gradually disappeared in the hydration products and a considerable amount of the expansive AFt was generated. 
comparison to the cement and the $\mathrm{CaO}$-slag. Therefore, it was expected that the hydration

products of $\mathrm{MgO}$-slag would contain much less $\mathrm{AFt}$, which would contribute to the improved

of the current study on the long term durability performance of $\mathrm{MgO}$-slag when cured in the

brine. Unfortunately, the experimental results indicated that the durability of the MgO-slag paste was poor when the corrosion ions existed (i.e. $\mathrm{Na}^{+}, \mathrm{Mg}^{2+}, \mathrm{Cl}^{-}, \mathrm{SO}_{4}{ }^{2-}$ ) in the curing environment. Therefore, it is recommended that MgO-slag should not be used for the

construction of the concrete structures in the salt lake areas.

\section{ACKNOWLEDGMENTS}

The authors gratefully acknowledge the financial support provided by the National Science

\section{REFERENCES}

[1] Hewlett P. Lea's chemistry of cement and concrete. Oxford: Butterworth-Heinemann; 2003.

[2] Neville AM. Properties of concrete. New Jersey: Prentice Hall; 1995.

[3] Mehta PK. Concrete. Structure, properties and materials. New York: McGraw-Hill; 1986.

[4] Lai HH. China's western development program: Its rationale, implementation, and prospects. Modern China, 2002; 28: 432-466.

[5] Liu LX. Brief introduction on the study of erosion and prevention of concrete in salt lake and saline soil area of Chaerhan, Chaida mu. Journal of Building Materials, 2001; 4: 395-400. 
[6] Mehta PK. Durability of concrete--fifty years of progress? Special Publication, 1991; 126: $1-32$.

[7] Jin ZQ, Sun W, Zhang YS, Jiang JY, Lai JZ. Interaction between sulfate and chloride solution attack of concretes with and without fly ash. Cement and Concrete Research, 2007; 37: 1223-1232.

[8] Thomas MDA, Bamforth PB. Modelling chloride diffusion in concrete: effect of fly ash and slag. Cement and Concrete Research, 1999; 29: 487-495.

[9] Song HW, Lee CH, Ann KY. Factors influencing chloride transport in concrete structures exposed to marine environments. Cement and Concrete Composites, 2008; 30: $113-121$.

[10] Sengul O, Gjørv OE, Tasdemir MA. Supplementary cementing materials for increased durability of concrete structures in severe environments. Concrete Durability and Service Life Planning-Concrete Life'09, 2016; 547-555.

[11]Li YL, Zhao XL, Singh RKR, Al-Saadi S. Tests on seawater and sea sand concrete-filled CFRP, BFRP and stainless steel tubular stub columns. Thin-Walled Structures, 2016; 108: $163-184$.

[12] Mostofinejad D, Nosouhian F, Monfared HN. Influence of magnesium sulphate concentration on durability of concrete containing micro-silica, slag and limestone powder using durability index. Construction and Building Materials, 2016; 117: 107-120.

[13] In KJ, Jiang YR, Jung SH, Lee MK, Yoo SW, Oh BH. Durability of Concrete under Combined Exposure Conditions of Chlorides and Sulfates. Key Engineering Materials, 2016; 711: 319-326.

[14]Brown PW, Badger S. The distributions of bound sulfates and chlorides in concrete subjected to mixed $\mathrm{NaCl}, \mathrm{MgSO} 4, \mathrm{Na} 2 \mathrm{SO} 4$ attack. Cement and Concrete Research, 2000; 30: 1535-1542.

[15]Delagrave A, Pigeona M, Marchanda J, Revertégat É. Influence of chloride ions and $\mathrm{pH}$ level on the durability of high performance cement pastes (part II). Cement and Concrete Research, 1996: 26: 749-760.

[16]Lubelli B, Nijlandb TG, Hees RPJV, Hacquebord A. Effect of mixed in crystallization inhibitor on resistance of lime-cement mortar against $\mathrm{NaCl}$ crystallization. Construction and Building Materials, 2010; 24: 2466-2472.

[17]Dan E, Janotka I. Chemical resistance of Portland cement, blast-furnace slag Portland cement and sulphoaluminate-belite cement in acid, chloride and sulphate solution: Some preliminary results. Ceramics Silikaty, 2003: 47: 141-148.

[18] Andrade C, Page CL. Pore solution chemistry and corrosion in hydrated cement systems containing chloride salts: a study of cation specific effects. British Corrosion Journal, 1986; 21: 49-54.

[19] Glasser FP, Pedersen J, Goldthorpe K, Atkins M. Solubility reactions of cement components with $\mathrm{NaCl}$ solutions: $\mathrm{I}$. $\mathrm{Ca}(\mathrm{OH})_{2}$ and $\mathrm{CSH}$. Advances in cement research, 2005; 17: 57-64.

[20]Wang FS, Qin XJ, Sun RL. Study on Corrosion and Destruction of Concrete Under Natural Conditions of Caerhan Salt Lake. Bulletin of the Chinese Ceramic Society, 2003; 4: $25-28$.

[21] Taylor HFW. Cement Chemistry. London: Telford Telford Publishing; 1997. 
[22]Zhang TW, Yue XB, Deng YF, Zhang DW, Liu SY. Mechanical behaviour and micro-structure of cement-stabilised marine clay with a metakaolin agent. Construction and Building Materials, 2014; 73: 51-57.

[23] Garg M, Pundir A. Comprehensive study of fly ash binder developed with fly ash-alpha gypsum plaster-Portland cement. Construction and Building Materials, 2012; 37: 758-765.

[24]Qiang Y, Shi CJ, Schutter GD, Audenaert K, Deng DH. Chloride binding of cement-based materials subjected to external chloride environment-a review. Construction and Building Materials, 2009; 23: 1-13.

[25] Neville AM, Wainwright PJ. High alumina cement concrete. Dundee: Halsted Press; 1975.

[26] Yang JW. Research on the hydraulic of magnesium oxychloride cement concrete in brine, Master thesis. Beihang University, China, 2014.

[27]Paul MM, Ravikumar P. Review on Development of Polymer Mortar Composite. International Journal of Engineering Science, 2016; 6: 7945-7948.

[28] Almeida IRD. Resistance of high strength concrete to sulfate attack: soaking and drying test. Special Publication, 1991; 126: 1073-1092.

[29] Chandra S, Ohama Y. Polymers in concrete. Boca Raton: CRC press; 1994.

[30] Ohama Y. Polymer-based materials for repair and improved durability: Japanese experience. Construction and building materials, 1996; 10: 77-82.

[31] Selvaraj R, Selvaraj M, Iyer SVK. Studies on the evaluation of the performance of organic coatings used for the prevention of corrosion of steel rebars in concrete structures. Progress in organic coatings, 2009; 64: 454-459.

[32] Wu C, Zhang Y, Hu Z. Properties and application of alkali-slag cement. Journal of the Chinese Ceramic Society, 1993; 21: 175-181.

[33] Atiş CD, Bilim C, Çelik Ö, Karahan O. Influence of activator on the strength and drying shrinkage of alkali-activated slag mortar. Construction and building materials, 2009; 23: 548-555.

[34]Domingo-Cabo A, Lázaroa C, López-Gayarreb F, Serrano-Lópezb MA, Sernaa P, Castaño-Tabares JO. Creep and shrinkage of recycled aggregate concrete. Construction and Building Materials, 2009; 23: 2545-2553.

[35] Jin F, Gu K, Al-Tabbaa A. Strength and hydration properties of reactive MgO-activated ground granulated blastfurnace slag paste. Cement and Concrete Composites, 2015; 57: 8-16.

[36] Yi YL, Al-Tabbaa A, Martin L. Properties and microstructure of GGBS-magnesia paste. Advances in Cement Research, 2014; 26: 114-122.

[37] Jin F, Gu K, Abdollahzadeh A, Al-Tabbaa A. Effect of different reactive MgOs on the hydration of $\mathrm{MgO}$-activated ground granulated blastfurnace slag paste. Journal of Materials in Civil Engineering, 2015; 27: 1-9.

[38] Jin F, Gu K, Al-Tabbaa A. Strength and drying shrinkage of reactive MgO modified alkali-activated slag paste. Construction and Building Materials, 2014; 51: 395-404.

[39] Shand MA. The chemistry and technology of magnesia. Hoboken, New Jersey: John Wiley \& Sons; 2006.

[40]Lide DR. CRC handbook of chemistry and physics. Boca Raton: CRC press; 2004. 
[41] Simakova A, Kudyakov A, Efremova V, Latypov A. The effects of complex glyoxal based modifiers on properties of cement paste and hardened cement paste. In N. Kopanitsa, AIP Conference Proceedings. AIP Publishing, 2017; 1800: 0200061-0200068.

[42] Števula L, Petrovič J. Formation of scawtite from mixtures of $\mathrm{CaO}$, magnesite and quartz under hydrothermal conditions. Cement and Concrete Research, 1981; 11: 549-557.

500 [43]Zaki DRSI. Application of ultra cellulose fiber for the enhancement of the durability and shrinkage of cement pastes exposed to normal and aggressive curing conditions. Nanotehnologii V Stroitel'stve: nauchnyj Internet-zhurnal, 2015; 7: 121-142.

[44]Callister WD. Materials Science and Engineering (Eighth Edition). John Wiley \& Sons; 2010. 